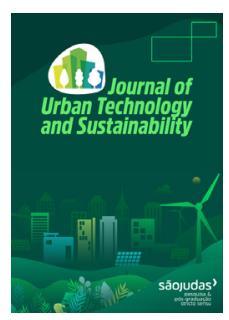

\title{
Surface corrosion in uncracked high-performance steel fibre reinforced cementitious composites
}

\author{
Mylene M. Vieiraa, b. *, Sergio H. P. Cavalaroc, Antonio Aguado ${ }^{d}$ \\ a Department of Civil Engineering, Federal University of Ceará, Campus Russas, 411 Felipe Santiago Street, 62900-000, Russas, Brazil. \\ ${ }^{b}$ CAPES Foundation, Ministry of Education of Brazil, Brasília - DF, 70040-020, Brazil. \\ 'School of Architecture, Building and Civil Engineering, Loughborough University, Leicestershire, UK. \\ d Department of Civil and Environmental Engineering, Barcelona Tech, Polytechnic University of Catalonia, UPC, Jordi Girona 1-3, 08034, Barcelona, Spain.
}

\section{Article info}

Received 15 November 2020.

Received in revised form 6 January 2021

Accepted 15 January 2021

\section{Keywords}

HPSFRCC

Steel fibre

Chlorides

Corrosion

Surface aspect
Abstract

High-performance steel fibre reinforced cementitious composites (HPSFRCCS) are usually produced with high fibre contents. Despite the very dense matrix of these materials, the ingress of detrimental agents such as chlorides may occur. The objective of this work is to evaluate the mechanisms and effects of corrosion in HPSFRCCS specimens in terms of surface aspect. Eight mixes of HPSFRCCs with different fibre contents $\left(40,80,120\right.$ and $\left.160 \mathrm{~kg} / \mathrm{m}^{3}\right)$, with the addition of chlorides were designed. Prismatic specimens were cast and exposed to two curing conditions: initially in wet room and then in climatic room. Surface aspect was assessed by visual analysis with the use of a classification criteria. Results showed that the chloride added to the mixes induced a damage related to the superficial aspect whereas specimens without chlorides presented no sign of corrosion over time.

\section{Corrosão superficial em compósitos cimentícios de alto desempenho reforçados com fibra de aço}

\section{Informações}

Recebido 15 Novembro

2020

Manuscrito revisado recebido 6 Janeiro 2021

Aceito 15 Janeiro 2021

Palavras-chave

HPSFRCC

Fibra de aço

Cloretos

Corrosão

Aspecto superficial
Resumo

Compósitos cimentícios de alto desempenho reforçados com fibra de aço (HPSFRCCs) são geralmente produzidos com altos teores de fibras. Apesar da alta densidade da matriz, pode ocorrer a entrada de agentes prejudiciais como os cloretos. O objetivo deste trabalho é avaliar os mecanismos e efeitos da corrosão em corpos de prova de HPSFRCCs em termos de aspecto superficial. Foram projetadas oito misturas de HPSFRCCS com diferentes teores de fibra $\left(40,80,120\right.$ e $\left.160 \mathrm{~kg} / \mathrm{m}^{3}\right)$ e com adição de cloretos. Os corpos de prova prismáticos foram moldados e expostos a duas condições de cura: inicialmente em câmara úmida e depois em câmara climática. O aspecto superficial foi avaliado por análise visual com o uso de um critério de classificação. Os resultados mostraram que o cloreto adicionado às misturas induziu danos relacionados ao aspecto superficial, enquanto os corpos de prova sem cloretos não apresentaram sinais de corrosão ao longo do tempo.

\section{Corrosión superficial en compósitos cementicios de alto disempeño reforzados con fibra de acero}

\section{Información}

Recibido 15 Noviembre 2020

Manuscrito revisado recibido

6 Enero 2021

Aceptado 15 Enero 2021

\section{Palabras clave}

HPSFRCC

Fibra de acero

Cloruros

Corrosión

Aspecto superficial

\section{Resumen}

Compósitos cementiceos de alto disempeño reforzados con fibra de acero (HPSFRCC) son generalmente producidos con alto contenido de fibra. A pesar de la alta densidad de la matriz, pueden entrar agentes nocivos como los cloruros. El objetivo de este trabajo es evaluar los mecanismos y efectos de la corrosión en muestras de HPSFRCC en términos de apariencia superficial. Se diseñaron ocho mezclas de HPSFRCC con diferentes contenidos de fibra $\left(40,80,120\right.$ y $\left.160 \mathrm{~kg} / \mathrm{m}^{3}\right)$ y con la adición de cloruros. Las probetas prismáticas fueron moldeados y expuestas a dos condiciones de curado: inicialmente en cámara húmeda y luego en cámara climática. El aspecto superficial se evaluó mediante análisis visual utilizando un criterio de clasificación. Los resultados indujeron que el cloruro agregado a las mezclas indujo daños relacionados con la apariencia de la superficie, mientras que las muestras sin cloruros no mostraron señales de corrosión con el tiempo.

*-- Corresponding author: Department of Civil Engineering, Federal University of Ceará, Campus Russas, 62900-000, Russas, Brazil.

E-mail address: mylene.melo@ufc.br (Mylene M. Vieira, ORCID 0000-0002-9321-0706)

https://doi.org/10.47842/juts.v4i1.28

ISSN: $2675-780 X$ 


\section{Introduction}

Fibre reinforced cementitious composite (FRCC) is a term commonly used for a broad class of materials with optimized properties. The improved properties of FRCCs increased the use of such materials in structural engineering applications. The advantages of using fibres in structural applications also increased the research on SFRC about four decades ago (BRANDT, 2008; JOHNSTON, 1982; MINDESS, 2007; NAAMAN, 2000).

Although fibre usage is currently limited to few applications, such as industrial floors, precast tunnel linings, sprayed concrete or thin shells, new design rules for FRC in structural codes may lead their application in several elements (fib, 2010; BERROCAL; LÖFGREN; LUNDGREN, 2018). However, the insufficient knowledge on the deterioration mechanisms regarding fibres corrosion contributes to a conservative design approach limiting the full potential of SFRC in structures (FRAZÃO et al., 2016; SOLGAARD; KÜTER; EDVARDSEN, 2010).

FRCCs consist of two basic components: a cementitious base material called matrix, which is reinforced by either steel or synthetic fibres (TRÜB, 2011). Despite an increased use of steel fibres in high-performance steel fibre reinforced composites (HPFRCC) structures, some doubts remain regarding their resistance to corrosion and durability. The high amount of fibres, particularly steel fibres, may also lead to some reduction in the chloride penetration resistance of concrete (AFROUGHSABET; BIOLZI; OZBAKKALOGLU, 2016).

Studies revealed a level of surface damage in SFRC under chloride exposure: corrosion spots of SFRC under chloride cycles (BALOUCH; FORTH; GRANJU, 2010); Extensive deposition of corrosion products on the surface of SFRC with low carbon fibres under marine cycles (MANGAT, P.S.; GURUSAMI, 1988); SFRC subjected to immersion in a $10 \%$ sodium chloride solution presented slight evidence of fibre corrosion on the surface (CORINALDESI; MORICONI, 2004); SFRC with recycled fibres showed severe corrosion at the superficial area under wet-dry cycles (SERNA; ARANGO, 2008); Limited surface corrosion in ultra-high performance concrete subjected to salt ponding tests was observed (ABBAS, 2014).
Possible causes of fibre corrosion located close to the specimen surface are high humidity fluctuations, high oxygen supply and carbonation of concrete. Furthermore, the randomly and uniformly distribution of fibres in the SFRC matrix let the fibres close to the surface almost without protection from the surrounding environment (MANGAT; GURUSAMY, 1987). The review on SFRC (MARCOSMESON et al., 2018) reveals that uncracked SFRC specimens present high corrosion resistance due to factors such as dense fibre/matrix ITZ, discontinuous nature of fibres, more uniform steel surface (in the case of cold drawing production process) and the short length of fibres.

Currently, there is limited understanding of the mechanisms governing chloride-induced corrosion of steel fibres in HPSFRCCs and their potential effects on the surface aspect. However, a large number of factors (quality of concrete, type and amount of fibres, age and conditions of exposure and the presence and size of cracks) involve the study of durability of SFRC exposed to chloride environment (MARCOS-MESON et al., 2018). Consequently, the influence of chlorides on the durability of SFRC is not yet clear. Therefore, a deep understanding of durability properties of HPSFRCCs in the presence of chlorides is fundamental.

The main objective of this paper is to study how chloride affects uncracked HPSFRCCs specimens in terms of surface aspect focussing on fibre corrosion mechanisms. An experimental programme was conducted with 8 mixes of HPSFRCCs produced with 4 different fibre contents (40,80, 120 and 160 $\mathrm{kg} / \mathrm{m}^{3}$ ) and chloride addition. Prismatic specimens were subjected to 2 curing conditions: humid chamber and climatic room. Visual analysis of the surface with the use of classification criteria was performed over time. Results showed that for the specimens with chlorides in the matrix, a level of surface corrosion was detected.

\section{Experimental methodology}

\subsection{Materials and mixes}

Two main variables were defined in the study: 
fibre content and ages of tests. The definition of materials and compositions was based on the HPSFRCC designed by Klein et al (2011). To ensure good workability and avoid the influence of the consolidation process on fibre orientation, selfcompacting mixes were used.

All mixes contain CEM I 42,5R, limestone fine aggregates with particle size distribution between 0-2 $\mathrm{mm}$ and 0-5 mm and limestone filler. Potable water from the public network of Barcelona was used, since it is acceptable according to the recommendations of EHE-O8 (CPH 2008) for structural concrete. The density and the water absorption of the aggregates were determined according to UNE-EN 1097-6 (AENOR, 2014) and considered to correct water/cement ratio. The total quantity of water (WT) was calculated with equation 1 considering the water absorption of the aggregates (Wabs), the theoretical water/cement ratio (Ww/c), water contained in the superplasticizer (Ws), water contained in the retarding admixture $(\mathrm{Wr})$ and the water due to humidity of the aggregates (Wh).

$W_{T}=W_{w / c}+W_{a b s}-W_{s}-W_{r}-W_{h}$

Mixes were produced with fibre contents of 40 , 80,120 and $160 \mathrm{~kg} / \mathrm{m}^{3}$, added in substitution of the equivalent volume of sand. A short straight steel fibre (Dramix ${ }^{\circledR}$ OL13/.20) with a high percentage of carbon and copper coating was selected. Properties of fibres are presented in Table 1.

To accelerate the access of chloride to the fibres and the corrosion process, $179.50 \mathrm{~g}$ of anhydrous sodium chloride was added per litre of mixing water. This value corresponds to half the saturation point of sodium chloride. Equivalent mixes with no chloride addition were also produced as reference.

Table 1. Properties of fibres used (provided by the manufacturer).

\begin{tabular}{cc}
\hline Property & Result \\
\hline Length $(\mathrm{I})$ & $13 \mathrm{~mm}$ \\
Diameter $(\mathrm{d})$ & $0.2 \mathrm{~mm}$ \\
Aspect ratio $(\mathrm{I} / \mathrm{d})$ & 62 \\
Tensile strength $\left(\mathrm{f}_{\mathrm{y}}\right)$ & $2600 \mathrm{MPa}$
\end{tabular}

To compensate variations of workability due to the addition of fibre and chloride into the matrix, two approaches are possible: the modification of the water content and the modification of superplasticizer content. The first option was discarded as it would imply a modification of porosity and the mechanical properties of different mixes. Therefore, to ensure similar workability, the amount of superplasticizer (Glenium C303 SCC) was modified. A retarding admixture (Basf Pozzolith $111 \mathrm{R})$ was also added to control the set acceleration effect due to the inclusion of sodium chloride.

Trials were conducted to adjust the dosage of superplasticizer and retarder that ensured a flow diameter of $(210 \pm 10) \mathrm{mm}$, measured according to UNE-EN 12350-5 (AENOR, 2009). All mixes were produced with amounts of superplasticizer ranging from 2 to 5\% by cement weight (bcw) and retarder ranging from 0.30 to $1 \%$ bcw until the target flow extent was achieved (Figure 1).

For the experimental programme, eight mixes were designed. Table 2 shows the final composition of mixes defined after the trials. It can be highlighted that the amount of paste remained constant for all mixes, whereas the amount of sand reduced with the increase of fibre content. Mixes with no chloride are identified by 'F_fibre content' and Mixes containing chloride are identified by ' $F$ fibre content - Cl'.

\subsection{Preparation of mixes and specimens}

A planetary mixer with 8-L capacity was used to produce all the mixes. First, water and cement were mixed for $60 \mathrm{~s}$ (paddle rotation and planetary
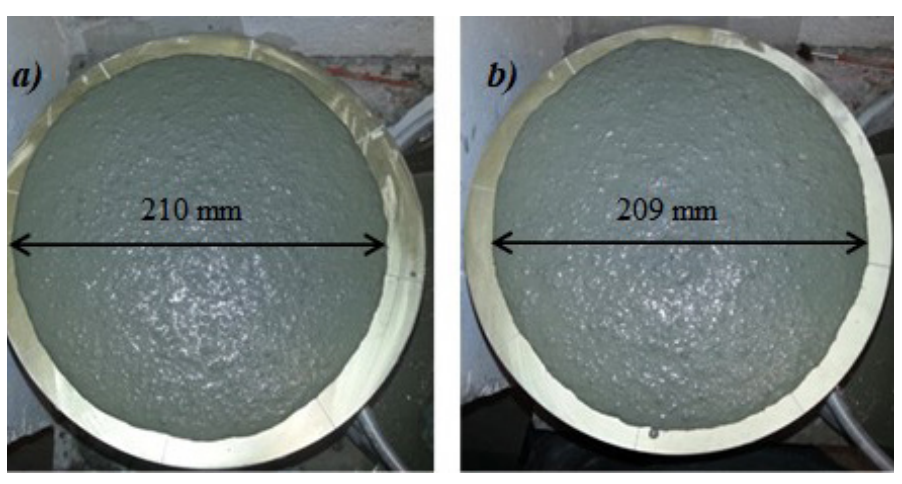

Fig. 1. Flow diameter: (a) mix without chlorides and (b) mix with chlorides. 
Table 2. Properties of fibres used (provided by the manufacturer).

\begin{tabular}{ccccccccc}
\hline Components & F_40 & F_80 & F_120 & F_160 & F_40 - Cl & F_80 - Cl & F_120 - Cl & F_160 - Cl \\
\hline CEM I 42.5 R $\left(\mathrm{kg} / \mathrm{m}^{3}\right)$ & 700 & 700 & 700 & 700 & 700 & 700 & 700 & 700 \\
Limestone filler $\left(\mathrm{kg} / \mathrm{m}^{3}\right)$ & 255 & 255 & 255 & 255 & 255 & 255 & 255 & 255 \\
Sand $(\mathbf{0} / 2 \mathrm{~mm})\left(\mathrm{kg} / \mathrm{m}^{3}\right)$ & 631.6 & 623 & 608.6 & 594.3 & 631.6 & 623 & 608.6 & 594.3 \\
Sand $(\mathrm{O} / 5 \mathrm{~mm})\left(\mathrm{kg} / \mathrm{m}^{3}\right)$ & 340.1 & 335.4 & 327.7 & 320 & 340.1 & 335.4 & 327.7 & 320 \\
Water $\left(\mathrm{kg} / \mathrm{m}^{3}\right)$ & 213.5 & 213.6 & 210.9 & 208.2 & 213.5 & 213.6 & 210.9 & 208.2 \\
Superplasticizer $\left(\mathrm{kg} / \mathrm{m}^{3}\right)$ & 31.5 & 31.5 & 35 & 38.5 & 31.5 & 31.5 & 35 & 38.5 \\
Retarder $\left(\mathrm{kg} / \mathrm{m}^{3}\right)$ & 2.1 & 2.1 & 2.1 & 2.1 & 2.1 & 2.1 & 2.1 & 2.1 \\
Steel fibre $\left(\mathrm{kg} / \mathrm{m}^{3}\right)$ & 40 & 80 & 120 & 160 & 40 & 80 & 120 & 160 \\
Sodium chloride $\left(\mathrm{kg} / \mathrm{m}^{3}\right)$ & - & - & - & - & 44 & 44 & 44 & 44 \\
Flow diameter $(\mathrm{mm})$ & 209 & 213 & 215 & 210 & 209 & 210 & 211 & 209 \\
\hline
\end{tabular}

speed equal to 140 and 62 rpm, respectively). Then the superplasticizer was added and homogenized for $60 \mathrm{~s}$ at the same speed. After that, the retarding admixture was added and mixed for $60 \mathrm{~s}$ at the same speed to ensure a proper homogenization of all components. Sand and filler were gradually added and mixed for an additional $60 \mathrm{~s}$ at the same speed.

To avoid accumulation of materials at the walls of the mixing bowl, the mixer was stopped for $90 \mathrm{~s}$ to remove and incorporate the material accumulated at the lateral surface of the mixing bowl. Then, the mix was homogenized for $60 \mathrm{~s}$ at the same speed. Fibres were carefully added and mixed for $90 \mathrm{~s}$ (paddle rotation and planetary speed equal to 285 and $125 \mathrm{rpm}$, respectively). Finally, sodium chloride was added (in the mixes with chlorides) and mixed for $90 \mathrm{~s}$.

After mixing (Figure 2a), mixes were cast in metallic moulds (Figure 2b) according to the UNE-EN 196-1 (AENOR, 2005) with no further consolidation. In total, 36 specimens measuring 40 $\mathrm{mm} \times 40 \mathrm{~mm} \times 160 \mathrm{~mm}$ (height $\times$ width $\times$ length) were produced per mix. Moulds were covered with a plastic sheet to avoid water loss by evaporation and kept in a controlled room at $24^{\circ} \mathrm{C}$. Specimens were removed from the moulds $24 \mathrm{~h}$ after casting and transferred to a humid chamber $\left(20^{\circ} \mathrm{C}\right.$ and 90\% relative humidity) for 44 days (Figure $2 \mathrm{c}$ ).

After that ( 45 days), specimens were transferred to a climatic room at $20{ }^{\circ} \mathrm{C}$ and $50 \%$ relative humidity (Figure $2 \mathrm{~d}$ ). Keeping specimens in the climatic room was necessary because the relative humidity influences the diffusion rate of oxygen enhancing the corrosion rate. In theory, in a saturated condition, almost no oxygen is available to enable the corrosion process. On the contrary, for lower relative humidity, oxygen is available and might lead to corrosion.

\subsection{Inspection of specimens}

A visual inspection of the specimen surfaces was performed to detect deposition of corrosion products that might affect their aesthetics aspect. This analysis was performed at the ages of 16,30 ,
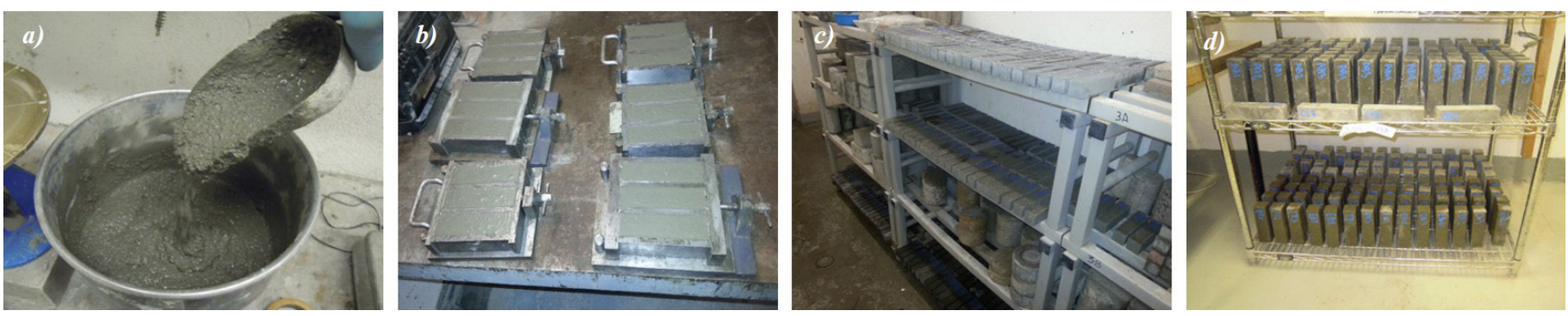

Fig. 2. Specimens preparation: (a) mix prepared, (b) mixes placed into metallic moulds, (c) curing in the wet room and (d) curing in the climatic room. 


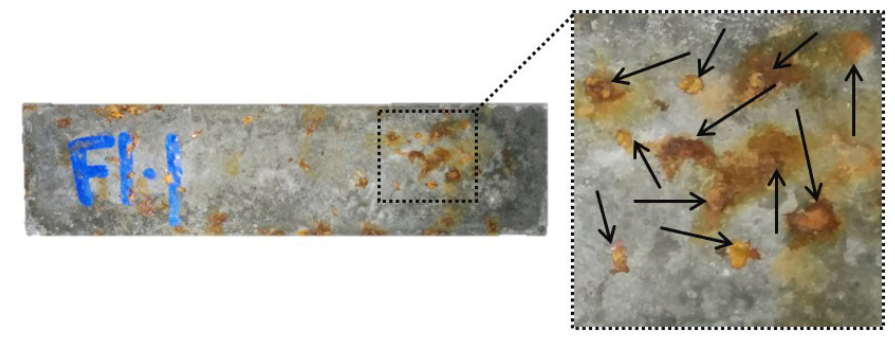

Fig. 3. Corrosion spots on the surface of the specimen.
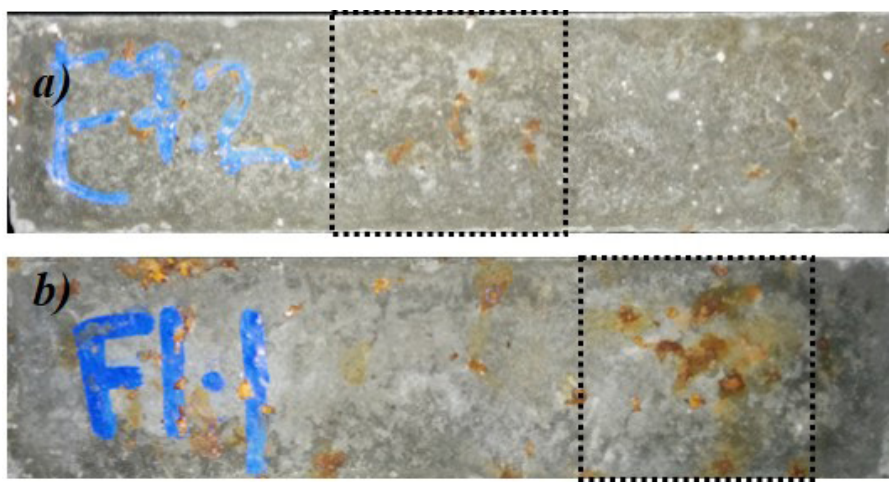

Fig. 4. Surface corrosion: (a) low level and (b) high level.

Table 3. Classification of levels of corrosion.

\begin{tabular}{cc}
\hline Level & Number of corrosion spots \\
\hline Low & $<10$ \\
Medium & $10-20$ \\
High & $>20$ \\
\hline
\end{tabular}

49 and 109 days, counting from the demoulding of specimens. Specimens were turned $90^{\circ}$ from the casting surface and one of the faces was selected for the analysis. The number of corrosion spots (Figure 3) was assessed and the criteria used to classify the level of corrosion were defined (Table 3). It should be highlighted that the criteria represent a qualitative analysis with the aim to measure and qualify the corrosion level. Similar analysis with the use of qualitative criteria to assess the surface corrosion was performed by Balouch, Forth and Granju (2010).

\section{Results and discussion}

\subsection{Analysis of the influence of chlorides}

Figure 4 presents the low and high levels of surface corrosion in specimens with chlorides. The average number of corrosion spots and the corrosion level (see Table 3) for mixes are summarized in Table 4.
Results in Table 4 show that no signs of corrosion were observed in specimens with no chlorides at any of the ages evaluated. Despite the availability of humidity and oxygen over time, fibres remained protected by the alkaline matrix. Under alkaline conditions, a very thin, dense and stable iron-oxide film is formed on the surface of the steel fibres. This film is a passive layer which reduces greatly the mobility of ions between the steel and the surrounding cementitious matrix. In addition, the lack of chlorides in the cementitious matrix did not induce corrosion initiation.

Surface corrosion was observed in all specimens containing chlorides. Corrosion spots observed at the surface may be attributed to two main phenomena: the chloride-induced corrosion of the steel fibre and the mobilization of corrosion products to the surface. The whole process includes the dissolution and oxidation of the iron and the precipitation of iron oxides.

The mechanisms of steel fibre corrosion involve the breakage of the passivating layer due to the presence of chlorides, the dissolution of iron and formation of ferrous hydroxide $\left(\mathrm{Fe}(\mathrm{OH})_{2}\right)$ and the insoluble ferric oxide $\left(\mathrm{Fe}_{2} \mathrm{O}_{3}\right)$. For fibres close to the surface, the corrosion process is more extensive due to the favoured exchange of oxygen and humidity, increasing the corrosion rate and the mobility of compounds that are subsequently deposited on the surface.

\subsection{Influence of time and curing conditions}

For the analysis of the influence of time and curing condition on fibre corrosion, the mechanisms during curing should be highlighted. Over time, specimens were subjected to two different curing conditions which favoured the corrosion process. One day after production, specimens were transferred to a humid chamber, where were kept for 44 days. After that, specimens were transferred to a climatic room until the age of the tests.

Figure 5 illustrates the corrosion mechanisms when specimens were kept in the humid chamber and climatic room. Since corrosion is an electrochemical process, the presence of chlorides 
Table 4. Number of corrosion spots and level of corrosion.

\begin{tabular}{|c|c|c|c|c|c|}
\hline Mix & Curing condition & $\begin{array}{l}\text { Age of test } \\
\text { (days) }\end{array}$ & $\begin{array}{c}\text { Average number of } \\
\text { corrosion spots (no } \\
\text { chlorides) }\end{array}$ & $\begin{array}{l}\text { Average number } \\
\text { of corrosion spots } \\
\text { (with chlorides) }\end{array}$ & $\begin{array}{l}\text { Corrosion level } \\
\text { (specimens with } \\
\text { chlorides) }\end{array}$ \\
\hline F_40 & Humid chamber & 16 & 0 & 6 & Low \\
\hline F_40 & Humid chamber & 30 & 0 & 8 & Low \\
\hline F_40 & Humid chamber and climatic room & 49 & 0 & 9 & Low \\
\hline F_40 & Humid chamber and climatic room & 109 & 0 & 9 & Low \\
\hline F_80 & Humid chamber & 16 & 0 & 12 & Medium \\
\hline F_80 & Humid chamber & 30 & 0 & 14 & Medium \\
\hline F_80 & Humid chamber and climatic room & 49 & 0 & 16 & Medium \\
\hline F_80 & Humid chamber and climatic room & 109 & 0 & 19 & Medium \\
\hline F_120 & Humid chamber & 16 & 0 & 16 & Medium \\
\hline F_120 & Humid chamber & 30 & 0 & 19 & Medium \\
\hline F_120 & Humid chamber and climatic room & 49 & 0 & 26 & High \\
\hline F_120 & Humid chamber and climatic room & 109 & 0 & 31 & High \\
\hline F_160 & Humid chamber & 16 & 0 & 17 & Medium \\
\hline F_160 & Humid chamber & 30 & 0 & 20 & High \\
\hline F_160 & Humid chamber and climatic room & 49 & 0 & 28 & High \\
\hline F_160 & Humid chamber and climatic room & 109 & 0 & 35 & High \\
\hline
\end{tabular}

in the mix provides thermodynamic conditions to induce corrosion. However, the kinetics of the process depends on the presence of oxygen and water. The electrochemical corrosion is not thermodynamically favourable without the simultaneous presence of oxygen and water.

During wet curing at 1 day (Figure 5a), specimens were saturated with water and a limited amount of oxygen could penetrate the matrix. Chlorides in the mix initiate corrosion in fibres close to the surface, consuming most of oxygen available. The presence of abundant water facilitates the movement of corrosion products that may reach the surface causing the first stain points. Over time and until 45 days (Figure $5 b$ ), corrosion progresses at slow rates due to the limited amount of oxygen. Consequently,
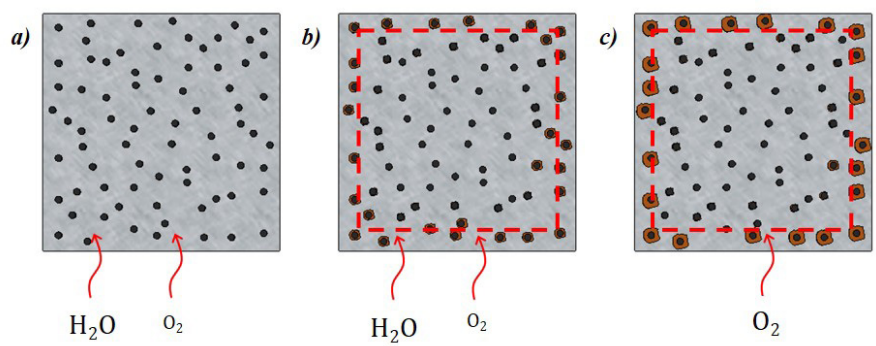

Fig. 5. Exposure to oxygen and humidity at both curing conditions over time: (a) humid chamber at 1 day, (b) humid chamber at 45 days, and (c) climatic room at 109 days. the rate of corrosion and formation of corrosion spots reduces.

After 45 days (Figure 5c), the change of curing condition to the climatic room reduces the availability of water and increases oxygen concentration, accelerating the corrosion rate of fibres close to the surface. The excess water inside the specimens tends to migrate to the specimen surface to reach an equilibrium with the new external environment. In the process, water brings iron oxides to the surface, also accelerating the formation of corrosion spots. Corrosion rate and the formation of corrosion spots should reduce as the amount of water at the surface decreases.

Based on these corrosion mechanisms, the influence of time and curing conditions are analysed for the samples with chlorides. The corrosion rate and the number of corrosion spots on the specimen surface were considered. Figure $6 a$ shows the rate of the formation of corrosion spots on the surface of the specimens and Figure $6 \mathrm{~b}$ presents the number of corrosion spots over time. The dotted line in Figure $6 \mathrm{~b}$ indicates the change of curing condition from the humid chamber to the climatic room at the age of 45 days.

The analysis at 16 days during the humid chamber 


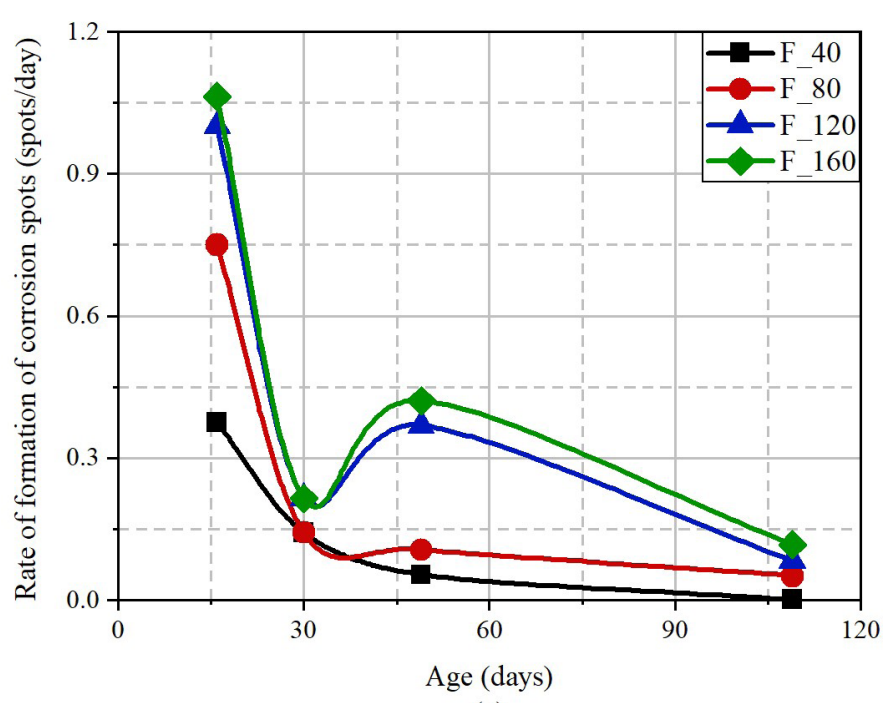

(a)

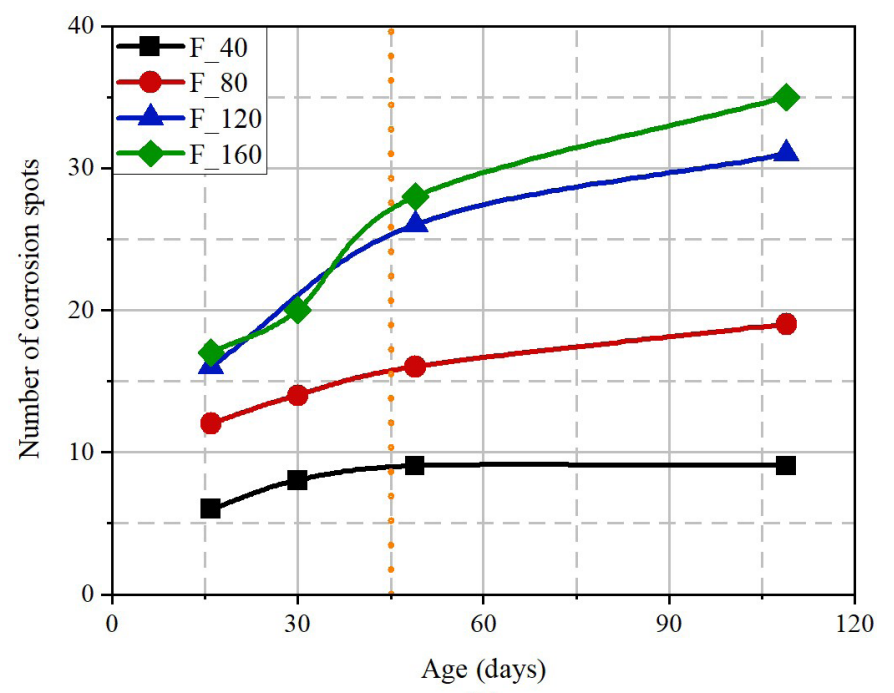

(b)

Fig. 6. Evolution of surface corrosion: (a) rate of formation of corrosion spots and (b) absolute number of corrosion spots on the specimen surface

curing shows the highest rate of formation of spots on the surface, confirming the mechanism described previously, suggesting that the available oxygen is consumed. Moreover, the presence of chlorides in the initiates corrosion. At the age of 30 days, a significant reduction on the rate of formation of corrosion spots was observed due to the consumption of the oxygen. Such phenomenon may be expected since corrosion occurs by means a cathodic reaction with the reduction of water and oxygen simultaneously with the anodic reaction of dissolution of iron (BROOMFIELD, 2019). The ingress of oxygen is also limited due to the high saturation of specimens.

The analysis at 49 days during the climatic room

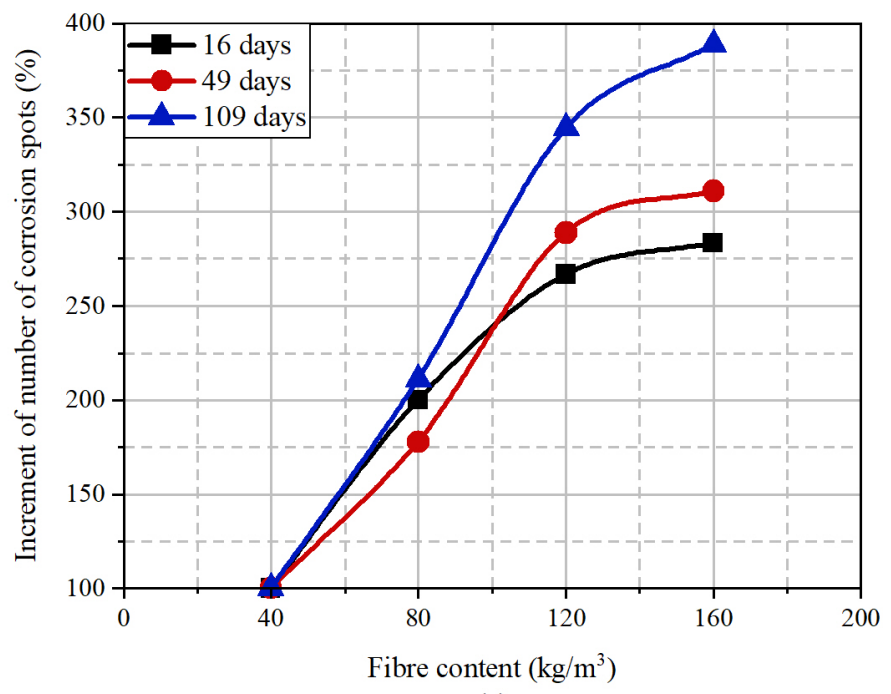

(a)

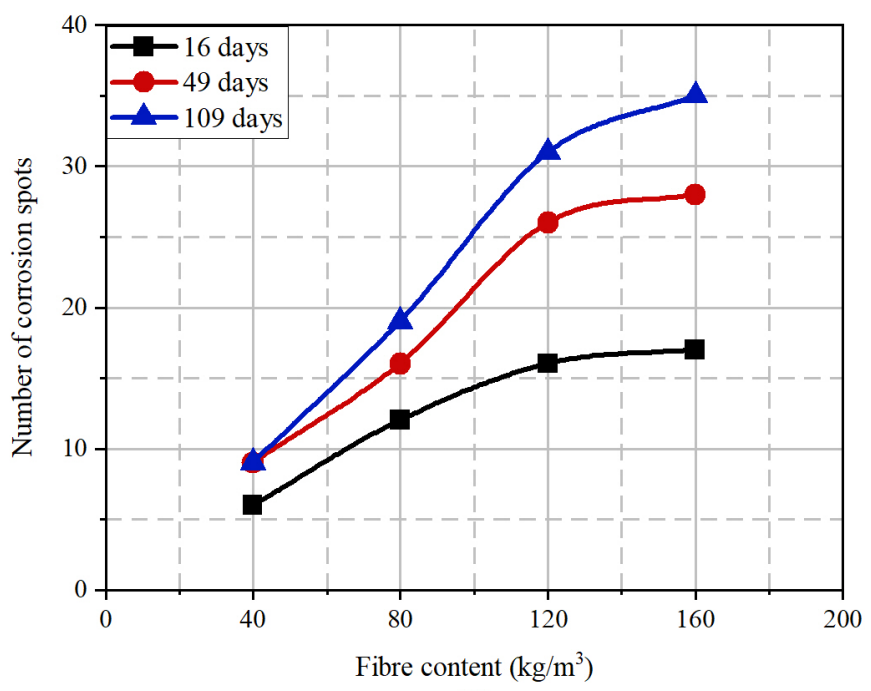

(b)

Fig. 7. Influence of the fibre content: (a) relative increment of number of corrosion spots and (b) number of corrosion spots.

curing shows a considerable increase on the rate of formation of corrosion spots in specimens from F_120 and F_160. These mixes present a larger volume of steel close to the surface, leading to an increased formation of corrosion spots. By contrast, specimens from F_40 and F_80 may have reached a high corrosion degree during curing in the humid chamber. The increment in terms of corrosions spots due to change of curing was significantly smaller since most of the spots had already been formed during curing in the humid chamber.

The analysis at 109 days during the climatic room curing shows the lowest rate of formation of corrosion spots. Although the availability of oxygen is high, at this age the degree of saturation of the 
surface was considerably reduced, limiting the corrosion progress and the mobility of the corrosion products towards the surface. In addition to that, most of the fibres had already been affected in previous ages, meaning that additional spots could not be formed.

\subsection{Influence of fibre content}

Figure 7 presents the percentage of increment of corrosion spots on the specimen surface for F_80, F_120 and F_160, considering the mix F_40 as reference. In all the cases, an increment of fibre content leads to a larger number of surface corrosion spots, which may be attributed to a larger number of fibres located close to the surface. The low water/cement ratio of the mixes creates a matrix with a low diffusion coefficient. Consequently, only fibres close to the surface have access to oxygen and water in the proportion needed to unchain corrosion and enable the movement of corrosion products to the surface.

An almost linear increase of the number of corrosion spots in mixes F_80 and F_120 was observed in Figure 7a. Interestingly, the linear increment does not hold for mix F_160. A possible explanation is that due to the high content, fibres close to the surface overlap, in which the deposition of the corrosion products of one fibre overlaps with those from other fibres. On the contrary, for lower fibre contents, fibres near the surface are located farther from each other and corrosion spots from individual fibres are formed independently. Another possible explanation is that the corrosion degree of individual fibres is lower in mixes with higher fibre contents since oxygen and water must be shared between a larger number of fibres.

\section{Conclusions}

- The presence of chlorides in the mixes led to the deposition of corrosion spots on the surface of specimens, whereas no corrosion spots were found in mixes produced with no chlorides.

- Curing in the humid chamber induced a significant corrosion level in specimens produced with chloride. Besides, specimen saturation contributed to the migration of corrosion products to specimen surface.

- The increment in the formation of corrosion spots is proportional to fibre content, which should be considered in structural elements with high aesthetic requirements.

\section{Acknowledgements}

The first author would like to thank CAPES (CAPES Foundation, Ministry of Education of Brazil, process 13117/2013-00) for the scholarship granted.

\section{References}

ABBAS, S. Structural and durability performance of precast segmental tunnel linings. 2014. Ph.D. (thesis in Civil and Environmental Engineering) University of Western Ontario, 2014.

AFROUGHSABET, V.; BIOLZI, L.; OZBAKKALOGLU, T. High-performance fiber-reinforced concrete: a review. Journal of Materials Science, v. 51, p. 65176551, 2016.

ASSOCIACIÓN ESPAÑOLA DE NORMALIZACIÓN Y CERTIFICACIÓN. UNE-EN 196-1: Métodos de ensayo de cementos - Parte 1: Determinación de resistencias mecánicas. Madrid: AENOR, 2005.

UNE-EN 12350-5: Ensayos de hormigón fresco - Parte 5: Ensayo de la mesa de sacudidas. Madrid: AENOR, 2009.

UNE-EN 1097-6: Ensayos para determinar las propiedades mecánicas y físicas de los áridos - Parte 6: Determinación de la densidad de e partículas y la absorción de agua. Madrid: AENOR, 2014.

BALOUCH, S. U.; FORTH, J. P.; GRANJU, J. L. Surface corrosion of steel fibre reinforced concrete. Cement and Concrete Research, v. 40, n. 3, p. 410-414, 2010. 
BERROCAL, C. G.; LÖFGREN, I.; LUNDGREN, K. The effect of fibres on steel bar corrosion and flexural behaviour of corroded RC beams. Engineering Structures, v. 163, p. 409-425, 2018.

BRANDT, A. M. Fibre reinforced cement-based (FRC) composites after over 40 years of development in building and civil engineering. Composite Structures, v. 86, n. 1-3, p. 3-9, 2008.

BROOMFIELD, J. P. Corrosion of steel in concrete: understanding, investigation and repair. $2^{\text {nd }}$ ed. CRC Press: Boca Raton, 2019.

CORINALDESI, V.; MORICONI, G. Durable fibre reinforced self-compacting concrete. Cement and Concrete Research, v. 34, n. 2, p. 249-254, 2004.

FRAZÃO, C. et al. Corrosion effects on pullout behavior of hooked steel fibers in self-compacting concrete. Cement and Concrete Research, v. 79, p. 112-122, 2016.

FIB (INTERNATIONAL FEDERATION FORSTRUCTURAL CONCRETE). Model Code 2010, 2010.

JOHNSTON, C. D. Steel fibre-reinforced concrete - present and future in engineering construction. Composites, v. 13, n. 2, p. 113-121, 1982.

KLEIN, N. S. et al. Hormigón ligero autocompactante con fibras para rehabilitación de forjados. Materiales de Construcción, v. 61, n. 302, p. 239-256, 2011.

MANGAT, P.S. AND GURUSAMI, K. Corrosion resistance of steel fibres in concrete under marine exposure. Cement and Concrete Research, v. 18, n. 2, p. 44-54, 1988.

MANGAT, P. S.; GURUSAMY, K. Permissible crack widths in steel fibre reinforced marine concrete. Materials and Structures, v. 20, n. 5, p. 338-347, 1987.

MARCOS-MESON, V. et al. Corrosion resistance of steel fibre reinforced concrete - A literature review. Cement and Concrete Composites, v. 103, p. 1-20,
2018.

MINDESS, S. Thirty years of fibre reinforced concrete research at the UWM British Colombia. In: Rudolph N. Kraus, Tarun.R. Naik, Peter Claisse, SadeghiPouya, ed. Proceedings: Sustainable construction materials and technologies, 11-13 June 2007 Coventry, Special papers proceedings, Pub. UW Milwaukee CBU, p. 259-268, 2007.

SERNA, P.; ARANGO, S. Evolution of the flexural behaviour of precracked SFRC in marine environment. In: 17th International RILEM Symposium on Fibre Reinforced Concrete: Design and Applications. Proceedings. Chennai, India: 2008.

TRÜB, M. Numerical modeling of high performance fiber reinforced cementitious composites. 2011. Ph.D. (thesis in Structural Engineering) - Swiss Federal Institute of Technology, 2011. 